\title{
URBAN INDIGENOUS COURTS: \\ POSSIBILITIES FOR INCREASING \\ COMMunity CONTROL OVER JUSTICE
}

\author{
GABE BOOTHROYD*
}

\begin{abstract}
The settler colonial justice system of the Canadian state continues to inflict immense harm on Indigenous people. One response to these harms could be the creation of urban Indigenous courts in line with the Truth and Reconciliation's call for Indigenous justice systems that are expressions of self-determination. While any initiative that operates within the confines of the mainstream justice system has significant limitations, the practices of existing courts that avoid convictions, apply Indigenous legal principles, and cede genuine control to Indigenous people and communities demonstrate the potential for a meaningful break from the status quo. The creation of an urban court could facilitate a resurgence of Indigenous justice while mitigating the harm caused by the settler colonial justice system.
\end{abstract}

\section{TABLE OF CONTENTS}

I. INTRODUCTION . . . . . . . . . . . . . . . . . . . . . . 904

II. DeCOlOnizATION AND APPROACHES to Justice . . . . . . . . . . . . . . . . 906

A. DeColonization In THE CONTEXT

OF JUSTICE SYSTEM REFORM . . . . . . . . . . . . . . . . . 906

B. Restorative Justice Paradigms And CRitiques . . . . . . . . . . 909

III. FaIluRES of CANADA's Justice SySTEM . . . . . . . . . . . . . . . . . 913

A. Historic AND ONGOING COlONIALISM

AND OVERREPRESENTATION $\ldots \ldots \ldots \ldots \ldots \ldots \ldots \ldots \ldots$

B. BRITISH COLUMBIA'S APPROACH

TO INDIGENOUS COURTS $\ldots \ldots \ldots \ldots \ldots \ldots \ldots \ldots \ldots \ldots$

IV. An URBAN IndigenOUS COURT . . . . . . . . . . . . . . . . . . . 919

A. FRAMEWORK FOR INDIGENOUS

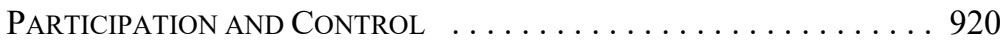

B. IndigenOUS LEGAL PRINCIPLES $\ldots \ldots \ldots \ldots \ldots \ldots \ldots \ldots \ldots \ldots 22$

C. Stays Rather Than Convictions $\ldots \ldots \ldots \ldots \ldots \ldots \ldots \ldots . \ldots 925$

D. Culturally APPRopriate Processes . . . . . . . . . . . . . 925

E. Contextual Understanding of the

IMPACTS OF COLONIALISM . . . . . . . . . . . . . . . . . . . . . . . 927

F. ANTI-COLONIAL NORMATIVE FRAMEWORK . . . . . . . . . . . . . . . . 928

G. INDIGENOUS COMMUNITY CONTROL OVER

Who ApPeArs Before the Court . . . . . . . . . . . . . . . . . . . . . . . . . . . 929

H. Protection of Due Process Rights . . . . . . . . . . . . . 930

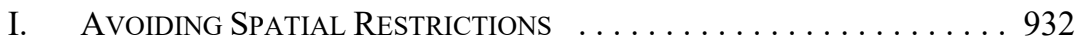

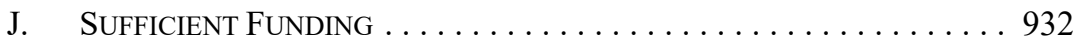

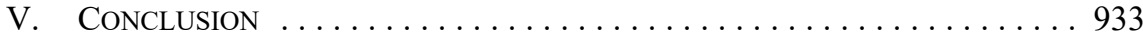

JD Candidate, Peter A Allard School of Law, University of British Columbia. The author would like to thank Patricia Barkaskas, Academic Director, Indigenous Community Legal Clinic who was the genesis of this project and provided a number of ideas for the content of the article. 


\section{INTRODUCTION}

We call upon the federal, provincial, and territorial governments to commit to the recognition and implementation of Aboriginal justice systems.

— Truth and Reconciliation Commission, Calls to Action ${ }^{1}$

On 12 August 2016 the Akwesasne Tekaia'torehthà:ke Kaianerenhsera (Akwesasne Court Law) entered into force in the Akwesasne Mohawk community. ${ }^{2}$ Established without federal or provincial authorization, the Akwesasne heralded the Court as "a landmark achievement for First Nations across Canada as it is the first aboriginal court created, sanctioned and enacted by an aboriginal community." 3 The stated purpose of the law is to exercise "the inherent right of self-government of the Mohawks of Akwesasne as recognized and affirmed by section 35 of the Constitution Act 1982 and by the United Nations Declaration on the Rights of Indigenous Peoples." "Not only is the court an expression of community control, it is a means to ensure that Mohawk legal traditions continue to govern the community's affairs. The preamble to the law states, "the Mohawks of Akwesasne recognize that indigenous legal institutions are required to meet its goal of a peaceful and harmonious society and to meet the collective needs of the Mohawks of Akwesasne." ${ }^{, 5}$ Professor Kirsten Anker refers to the Akwesasne Court as "a model and a source of inspiration" for other Indigenous peoples and recently visited the community along with a Saskatchewan Cree delegation. ${ }^{6}$ In my view, the initiative provides a potent example of how Indigenous nations can enact the Truth and Reconciliation Commission's (TRC) call for the creation of Indigenous justice systems that are expressions of "Aboriginal self-determination and selfgovernment."

In addition to the Akwesasne Court and other community-specific projects, ${ }^{8}$ a number of courts have been established in Canada's urban areas that seek to better serve the needs of diverse Indigenous populations. These courts incorporate various adjustments to the mainstream justice system, including broadly construed Indigenous principles of justice, more culturally appropriate processes, and a greater awareness of the social context that can

Truth and Reconciliation Commission of Canada, Calls to Action (Winnipeg: TRC, 2015) at 4, online: $<$ www.trc.ca/websites/trcinstitution/File/2015/Findings/Calls to Action English2.pdf $>$.

Mohawk Council of Akwesasne, "Akwesasne Court Law Come-s Into Force" (6 September 2016), online: <www.akwesasne.ca/node/827>.

Ibid.

Mohawk Council of Akwesasne, Akwesasne Tekaia'torehthà:keKaianerénhsera (Akwesasne Court Law), Kaiahnehronshera iehiontakwa No 2016-01 (12 February 2016), online: <webdev.akwesasne.ca/ wp-content/uploads/2017/07/mcr-atk-ac12016.pdf> [Akwesasne Court Law].

Ibid.

Giuseppe Valiante, “Akwesasne Creates First Court in Canada For and By Indigenous People," CBC News (2 October 2016), online: <www.cbc.ca/news/canada/montreal/akwesasne-indigenous-courtcanada-1.3787969>.

Truth and Reconciliation Commission of Canada, Honouring the Truth, Reconciling for the Future: Summary of the Final Report of the Truth and Reconciliation Commission of Canada (Ottawa: TRC, 2015) at 228, online: <www.trc.ca/websites/trcinstitution/File/2015/Findings/Exec Summary 2015 05 31_web_o.pdf $>$ [TRC, Honouring the Truth].

8 See e.g. Teslin Tlingit Council, "Peacemaker Court," online: <www.ttc-teslin.com/peacemakercourt.html>; Hadley Louise Friedland, Reclaiming the Language of Law: The Contemporary Articulation and Application of Cree Legal Principles in Canada (PhD Thesis, University of Alberta Faculty of Law, 2016), online: <era.library.ualberta.ca/files/c3r074t97b/Friedland_Hadley_L_201603_ PhD.pdf $>$. 
bring Indigenous people into the justice system. ${ }^{9}$ While these courts have various relationships with, and participation by, local Indigenous communities, they are not directly controlled by any one Indigenous nation. Rather, they are firmly grounded in the settler colonial legal structure. In this article, I examine how an urban Indigenous court might be constituted so as to provide greater control to Indigenous communities and better mitigate the harms created by the settler legal system. In effect, I ask how a court might be developed in an urban area that, similarly to the Akwesasne Court, is an exercise of Indigenous selfdetermination.

Though I am unable to provide definitive answers to the question of what an urban Indigenous court should look like, ${ }^{10}$ I hope by drawing together empirical and theoretical material I can assist in adding to a base of knowledge that would assist in the development of such a project. Though there are likely similar issues confronting urban areas across Canada, my empirical focus is on British Columbia, and, in particular, I discuss the achievements and challenges of British Columbia's First Nations Courts (FNCs) ${ }^{11}$ and the Vancouver Aboriginal Transformative Justice Services Society (VATJSS). ${ }^{12}$ I begin in Part II by discussing the concept of decolonization and consider the issues raised in advancing institutional reforms that, nevertheless, seek to challenge entrenched power structures. I then briefly survey the theoretical literature that has informed the development of Indigenousoriented courts and has analyzed their effects. In Part III, I discuss the harms wrought to Indigenous people by the Canadian justice system and the attempts to mitigate that harm through the establishment of diversion programs and alternative courts. I also analyze British Columbia's recently adopted "Specialized Courts Strategy,"13 arguing that it is a problematic framework for the evaluation and establishment of Indigenous courts. In Part IV, I consider the specific features that an urban Indigenous court could incorporate, drawing ideas from existing Indigenous-focused courts in British Columbia, other parts of Canada, and other settler colonial states. I focus on how control over courts can be ceded to Indigenous communities, pointing to examples where community organizations and Elders have played key roles in justice initiatives and where Indigenous legal principles have been incorporated into court processes. I also focus on the potential of urban Indigenous courts to mitigate the harm of the settler colonial legal system, through instituting culturally appropriate processes,

9 These include First Nations Courts in British Columbia: see Shelly Johnson, "Developing First Nations Courts in Canada: Elders As Foundational to Indigenous Therapeutic Jurisprudence +" (2014) 3:2 J Indigenous Social Development 1; Aboriginal Persons (Gladue) Courts in Ontario: see Paula Maurutto \& Kelly Hannah-Moffat, "Aboriginal Knowledges in Specialized Courts: Emerging Practices in Gladue Courts" (2016) 31:3 CJLS 451 [Maurutto \& Hannah-Moffat, "Gladue Courts"]; sentencing circles in Saskatchewan and Yukon circuit courts: see Luke McNamara, "The Locus of Decision-Making Authority in Circle Sentencing: The Significance of Criteria and Guidelines" (2000) 18 Windsor YB Access Just 60.

10 I am a settler currently occupying and trespassing upon stolen Musqueam, Squamish, and TsleilWaututh land and, thus, do not wish to make claims regarding the interests of Indigenous peoples. Further, and as I describe further below, a community-led process and in-depth consultation would be a necessary part of the establishment of an urban Indigenous court.

11 There are currently six FNCs operating in British Columbia, with the Prince George Court beginning operations in early 2018: see Provincial Court of British Columbia, "New First Nations Court in Prince George to Improve Delivery of Justice" (22 January 2018), online: <www.provincialcourt.British Columbia.ca/downloads/announcements/Announcement-Jan-22-18\%20New\%20First\%20Nations $\% 20$ Court.pdf $>$.

12 VATJSS is an alternative measures program that I discuss in detail in Part III, below.

British Columbia, Ministry of Justice, "Specialized Courts Strategy" (March 2016), online: <www2.gov. bc.ca/assets/gov/law-crime-and-justice/about-bc-justice-system/justice-reform-initiatives/specializedcourts-strategy.pdf>. 
avoiding criminal convictions, protecting due process rights, and reducing the use of spatial restrictions for those who appear before the court. Part V offers a conclusion.

\section{DECOLONIZATION AND APPROACHES TO JUSTICE}

\section{A. Decolonization in the Context OF JUSTICE SYSTEM REFORM}

I start with a brief discussion of decolonization in order to situate my analysis of justice system reform. Though changes to the Canadian justice system are urgently needed, I do not wish to imply that the reforms I discuss in this article would, in themselves, undo the historic and ongoing harm caused by the settler colonial justice system or fundamentally alter settler colonial power structures. Rather, as Eve Tuck and K. Wayne Yang forcefully articulate, decolonization "requires the repatriation of Indigenous land and life."14 It is a radical break that is profoundly unsettling to the settler colonial state. As such, Tuck and Yang warn against the "too-easy adoption of decolonizing discourse" in progressive political programs that do not specifically work to destabilize the structure of settler colonialism and repatriate Indigenous land and sovereignty. ${ }^{15}$ Such programs include what Tuck and Yang call "settler harm reduction," which seeks to alleviate the deleterious effects of settler colonialism on Indigenous peoples. ${ }^{16}$ While important, even necessary, to address the significant ongoing harms experienced by Indigenous people, these measures should not be confused with, and do not necessarily contribute to, projects of decolonization. ${ }^{17}$

In addition to their inherent limitations, there is a danger that progressive political programs seeking to empower Indigenous people can in practice work to reify settler colonial state structures. Glen Coulthard argues that state-led processes of reconciliation, in particular, have the potential to channel Indigenous peoples' political energies away from reconstituting and reinvigorating their own political orders and into achieving recognition from the settler colonial state. ${ }^{18}$ As Corey Snelgrove, Rita Dhamoon, and Jeff Corntassel write, political analyses and programs that pay insufficient attention to "Indigenous peoples own articulations of Indigenous-settler relations, their governance, legal, and diplomatic orders, and the transformative visions entailed within Indigenous political thought" serve to obscure alternatives to the settler colonial state, thereby construing it as a structural inevitability. ${ }^{19}$ Indigeneity, Education \& Society 1 at 21

Ibid at 3

Ibid at 21

Ibid at 22 .

Glen Sean Coulthard, Red Skin, White Masks: Rejecting the Colonial Politics of Recognition (Minneapolis: University of Minnesota Press, 2014).

Corey Snelgrove, Rita Kaur Dhamoon \& Jeff Corntassel, “Unsettling Settler Colonialism: The Discourse and Politics of Settlers, and Solidarity with Indigenous Nations" (2014) 3:2 Decolonization: Indigeneity, Education \& Society 1 at 26. 
Specifically within the criminal justice system, programs that aim to better accommodate and recognize Indigenous peoples and principles have been criticized as potentially undermining the development of sovereign Indigenous institutions. As Elizabeth AdjinTettey states:

\begin{abstract}
Integrating Aboriginal communities and justice traditions into the Euro-Canadian criminal justice system is a far cry from the demands of Aboriginal people for institutional autonomy over the administration of justice as part of self-government. Reforms within the Euro-Canadian justice system have been perceived by some as assimilationist and an inadequate solution to the problem of Aboriginal over-representation in the criminal justice system, among other things, because it relies on colonial structures to solve problems created by that system, essentially trying to dismantle the master's house with the master's own tools. ${ }^{20}$
\end{abstract}

Mohawk law professor and activist Patricia Monture-Angus similarly argues that justice system reforms such as the introduction of native court workers and Elder participation in sentencing circles cannot effect substantial change:

[T]here is nothing intrinsically Aboriginal about these processes. We did not "sentence," and merely rearranging the furniture so we are sitting in a "circle" does not accomplish systemic or transformative change. Granted, a sentencing circle does borrow from Aboriginal traditions of dispute resolution as well as healing. Sentencing circles are accommodations of the mainstream process that may hold a better opportunity to provide a degree of comfort to community members, (Aboriginal) victims, and/or the Aboriginal accused. The sentencing circle may change the momentary experience of the Aboriginal person of criminal justice, but it does not really hold greater potential. ${ }^{21}$

She argues that these processes serve simply to conceal the lack of systemic change behind a facade of improved results for individuals: "[ $\mathrm{t}] \mathrm{his}$ is one of the fundamental characteristics of oppression by assimilation. It appears as though change has occurred when it has not." 22 Examining the incorporation of Aboriginal customary law into settler courts in Australia, Heather Douglas also describes a potential assimilative effect from these processes. ${ }^{23}$ She argues that, while these reforms create space for Indigenous people and culture within legal processes, entering that space requires Indigenous people to constitute themselves as subjects of the settler colonial legal order. ${ }^{24}$ In addition to these problems, the stark fact of rising overincarceration of Indigenous people shows that these programs have not succeeded in creating fundamental change. ${ }^{25}$

These are important critiques and they indicate the limited efficacy and potential dangers of interventions that do not thoroughly disrupt the hegemonic settler colonial status quo. Nevertheless, in this article I intend to only examine relatively limited reforms. This is for

Elizabeth Adjin-Tettey, "Sentencing Aboriginal Offenders: Balancing Offenders' Needs, the Interests of Victims and Society, and the Decolonization of Aboriginal Peoples" (2007) 19:1 CJWL 182 at n 7. Patricia Monture-Angus, "Standing Against Canadian Law: Naming Omissions of Race, Culture, and Gender" in Elizabeth Comack, ed, Locating Law: Race/Class/Gender Connections (Halifax: Fernwood Press, 1999) 76 at 81.

Ibid at 79 .

See Heather Douglas, "Customary Law, Sentencing and the Limits of the State" (2005) 20 CJLS 141 at 148 .

Ibid.

Patricia Monture-Angus pointed this out in 1999, and, unfortunately, it still holds true today: MontureAngus, supra note 21 at 81 . 
three reasons. First, I am not in a position to state what Indigenous people and communities can or should do to strengthen Indigenous legal systems. As a settler law student I am able, primarily, to consider ways in which the harm of the Canadian justice system on Indigenous people can be mitigated and space can be created within that system for Indigenous legal norms, while I continue to express support and solidarity with those working to upend that system entirely.

Second, for the time being least, a dichotomy cannot necessarily be constructed between Indigenous and Canadian legal systems. Because of the interactions and interrelationship between Indigenous culture, customs, and traditions and Canada, John Borrows argues that Indigenous control over Canadian institutions provides for greater self-determination. ${ }^{26}$ Consultations with Elders in the development of VATJSS revealed a similar sentiment reforms to the mainstream justice system could lead to increasing Indigenous control over justice, provided that the mainstream system ceded ground to the Indigenous community. ${ }^{27}$ A related argument is that Indigenous people are currently subject to, and significantly impacted by, the settler-colonial system of justice and, thus, reforms to mitigate that impact are an immediate necessity. Adjin-Tettey explains her own intervention, which "focuses on reform within the Euro-Canadian criminal justice system" ${ }^{28}$ rather than the development of sovereign Indigenous systems, by stating that

\footnotetext{
given the considerable convergence that has developed between the Aboriginal and non-Aboriginal systems through colonization, linkages between the two systems are inevitable and Aboriginal people will have to continue engaging with the Euro-Canadian system until full institutional autonomy for Aboriginal justice systems becomes a reality. ${ }^{29}$
}

Finally, demands for reforms can be a part of creating the political space to achieve more radical restructuring. British Columbia's FNCs, for example, would likely have been impugned as "race-based" justice and deemed politically unthinkable in the very recent past. $^{30}$ The societal changes that manifested legally in the amendments to the Criminal Code $^{31}$ and the Supreme Court of Canada's decision in R. v. Gladue ${ }^{32}$ laid the groundwork for a reconceptualization of how the Canadian justice system can work with and for Indigenous people. The development of FNCs have perhaps fostered a further recognition among mainstream legal actors of the possible roles for Indigenous law and perspectives. In this vein, Patricia Barkaskas and Sarah Buhler write:

Employing Indigenous legal mechanisms when possible, for example in First Nations or Gladue courts, may provide examples of new frameworks for justice in societies like Canada where the legal system is failing

John Borrows, Recovering Canada: The Resurgence of Indigenous Law (Toronto: University of Toronto Press, 2002) at 148 .

Tammy T'at'usayalthim Dorward, The Role of "Community" in the Design and Development of Vancouver Aboriginal Transformative Justice Services (MA Thesis, Simon Fraser University School of Criminology, 2005) at 58, online: <ir.lib.sfu.ca/handle/1892/724>. Adjin-Tettey, supra note 20 at 182.

Ibid.

See e.g. Jean Chretien, "Statement of the Government of Canada on Indian Policy (The White Paper)" (1969), online:<www.aadnc-aandc.gc.ca/DAM/DAM-INTER-HQ/STAGING/texte-text/cp1969_1100 100010190 eng.pdf $>$. 
those most in need of its protection. Truly engaging with Indigenous legal principles may radically transform the very notion of justice. ${ }^{33}$

With this in mind, I intend to explore possibilities for change within the context of the current political and institutional framework of the Canadian state. To this end, I examine existing courts in Canada and other settler colonial states that, at least in some aspects, hold promise for an Indigenous-controlled court in urban areas. Before addressing the empirical examples, however, I will briefly survey the theoretical literature that has informed the development of alternative courts.

\section{B. Restorative Justice Paradigms and CritiQues}

The courts that I discuss in this article are, for the most part, explicitly centred around a restorative justice framework. ${ }^{34}$ According to Howard Zehr, one of the concept's pioneers, restorative justice is based on three primary principles: (1) a focus on the harm experienced by victims, communities and those who have committed offences and the needs of each of these parties; (2) an emphasis on accountability and responsibility, particularly the obligations that are created from having caused harm but also broader societal obligations to repair relationships; and (3) the promotion of broad engagement by stakeholders, including victims and members of the community. ${ }^{35}$ A related concept that underlies many Indigenousoriented and other specialized court models is therapeutic jurisprudence, which focuses on the effects of legal rules and procedures on participants in the justice system. ${ }^{36}$ Therapeutic jurisprudence principles emphasize that legal processes and actors within the justice system should be oriented towards achieving a positive effect on participants' well-being, while respecting other important principles such as due process rights. ${ }^{37} \mathrm{Within}$ the context of court procedures, therapeutic jurisprudence emphasizes the fostering of participants' autonomy and self-determination in order to engender acceptance of the legitimacy of court processes and to motivate change. ${ }^{38}$

The concepts of restorative justice and therapeutic jurisprudence have been incorporated over the past three decades into a number of new court initiatives, including drug courts, ${ }^{39}$

Paricia Barkaskas \& Sarah Buhler, "Beyond Reconciliation: Decolonizing Clinical Legal Education" (2017) 26 JL \& Soc Pol'y 1 at 19.

See e.g. Yvon Dandurand \& Annette Vogt, "Documenting the Experience and the Successes of Firs Nations Courts in British Columbia" (Report delivered at the Office of the Chief Judge of the Provincial Court of British Columbia and the Legal Services Society of British Columbia, 2017) at 2, online: $<$ https://icclr.law.ubc.ca/wp-content/uploads/2017/09/Documenting-the-Experience-of-First-NationsCourts 2506 2017.pdf>; Akwesasne Court Law, supra note 4 at 11-13.

35 Howard Zèhr, The Little Book of Restorative Justice: Revised and Updated (Delaware: Skyhorse Publishing, 2015).

Michael S King, "Restorative Justice, Therapeutic Jurisprudence and the Rise of Emotionally Intelligent Justice" (2008) 32:3 Melbourne UL Rev 1096.

Ibid.

Bruce J Winick, “On Autonomy: Legal and Psychological Perspectives” (1992) 37:6 Vill L Rev 1705 at $1715-21$.

39 See Canada, Department of Justice, "Drug Treatment Court Funding Program Evaluation Final Report" (2015), online: <www.justice.gc.ca/eng/rp-pr/cp-pm/eval/rep-rap/2015/dtcfp-pfttt/dtcfp-pfttt.pdf> [Department of Justice, "Drug Treatment Court"]; James L Nolan Jr, "Redefining Criminal Courts: Problem-Solving and the Meaning of Justice" (2003) 40:4 Am Crim L Rev 1541. 
domestic violence courts, ${ }^{40}$ community courts, ${ }^{41}$ and mental health courts ${ }^{42}$ Each of these fall under the broad rubric of problem-solving courts, which, generally, place the judge in the role of facilitating rehabilitation and combines the authority of the courts and enhanced service provision within the context of a less adversarial, more outcome-oriented court process. ${ }^{43}$ Jane Spinak describes the common features of problem-solving courts as follows: "(1) an activist judge who helps to fashion, and then closely monitor, dispositions; (2) a team of lawyers, social workers, and court personnel who try to identify and then work toward common goals with the family; and (3) frequent and meaningful court appearances by relevant parties. ${ }^{\prime 4}$ Many argue that problem-solving courts have significant benefits including a more individualized approach to sentencing that prioritizes treatment and restitution over incarceration, ${ }^{45}$ judges and other legal actors who better appreciate the circumstances that bring people before the courts, ${ }^{46}$ and a reduction in recidivism. ${ }^{47}$

The Indigenous-oriented courts that I discuss in this article can be considered problemsolving courts, however, they typically incorporate features of Indigenous cultures into their distinctive court processes. Joseph Flies-Away, a judge in the Hualapai Healing to Wellness Courts, has developed the concept of Indigenous Therapeutic Jurisprudence + (Indigenous $\mathrm{TJ}+$ ) to denote the added value of Indigenous spirituality and Elders in achieving therapeutic court processes. ${ }^{48}$ Shelley Johnson applies this concept to analyze a variety of Indigenousoriented courts, including British Columbia's FNCs, and describes how these principles have led to a revitalization of traditional knowledge and spirituality. ${ }^{49}$ Court processes based on Indigenous spiritual traditions can, according to Flies-Away and Carrie Garrow, better address the trauma and addiction that causes many people to appear before the courts. ${ }^{50}$ Further, the enactment of these traditions within court processes supports Indigenous communities' spiritual strength and capacity for self-determination. ${ }^{51}$

While Flies-Away and Garrow discuss the relatively autonomous tribal courts in the United States, there are significant questions surrounding the effects of problem-solving courts that operate within the context of hegemonic settler colonial legal regimes. Carolyn

See e.g. British Columbia's Domestic Violence Courts: see Ministry of Justice, "Specialized Courts Strategy," supra note 13.

See e.g. Vancouver's Downtown Community Court, ibid.

See e.g. John S Goldkamp \& Cheryl Irons-Guynn, Emerging Judicial Strategies for the Mentally Ill in the Criminal Caseload: Mental Health Courts in Fort Lauderdale, Seattle, San Bernardino, and Anchorage (Washington, DC: Crime and Justice Research Institute, 2000), online: <www.ncjrs.gov/ pdffiles $1 /$ bja/182504.pdf $>$.

Phil Bowen \& Stephen Whitehead, Problem-Solving Courts: An Evidence Review (London: Centre for Justice Innovation), online: < justiceinnovation.org/wp-content/uploads/2016/08/Problem-solving-courtsAn-evidence-review.pdf $>$; Nolan Jr, supra note 39 at 1548.

Jane M Spinak, "A Conversation About Problem-Solving Courts: Take 2" (2010) 10 U Maryland LJ Race, Religion, Gender \& Class 113 at 114.

Greg Berman, "Redefining Criminal Courts: Problem-Solving and the Meaning of Justice" (2004) 41:3 Am Crim L Rev 1313 at 1316.

Susan Goldberg, Problem Solving in Canada's Courtrooms: A Guide to Therapeutic Justice (Ottawa: National Judicial Institute, 2011) at 59, online: <www.nji-inm.ca/index.cfm/publications/problemsolving-in-canada-s-courtrooms-a-guide-to-therapeutic-justice-2nd-edition> .

See e.g. Department of Justice, "Drug Treatment Court," supra note 39.

Joseph Thomas Flies-Away \& Carrie E Garrow, "Healing to Wellness Courts: Therapeutic Jurisprudence +" (2013) 2 Michigan State L Rev 403 at 407.

Johnson, supra note 9. See also Shelly Johnson \& Samantha Sarra, "International Indigenous Therapeutic Jurisprudence +: Rekindling Ancient Knowledge" (Paper delivered at the International Indigenous Development Research Conference, 2014) 66.

Flies-Away \& Garrow, supra note 48 at 439.

Ibid. 
Boyes-Watson argues that when the state basis for restorative justice programs is obscured there is a risk that they will facilitate the continuation of coercive, violent state power, rather than create a genuine shift in the framework of the justice system. ${ }^{52}$ The development of problem-solving courts can also work to legitimize the justice system as the appropriate site of intervention for social problems and, by extension, focus responsibility on the individual rather than the structural and systemic issues that are largely responsible for these problems. ${ }^{53}$

Increased state control over communities can, in particular, occur through the related issues of "net-widening" 54 and "intervention over-dosing." " Net-widening occurs when people who previously would have been diverted from the formal justice system, through either police or Crown discretion, are enrolled into court processes due to the apparent benefits that problem-solving courts commonly offer. ${ }^{56}$ In other words, rather than simply diverting people from traditional court processes, new, seemingly more benign courts run the risk of increasing the number of people brought before courts and receiving formal sanctions. For example, a government evaluation of youth-focused problem-solving courts in Scotland found they "may have encouraged prosecution in cases that might previously have attracted an alternative," additional young people into the judicial system." ${ }^{, 5}$ Particularly where communities lack resources, the ability of courts to provide access to services may cause justice system actors to push people into the court system as a means of receiving assistance. ${ }^{59} \mathrm{~A}$ report to the Provincial Government of British Columbia raised the question of whether such problems are present within the province's FNCs, but noted that the data necessary to answer these questions are currently lacking. ${ }^{60}$

Intervention over-dosing describes the concern that problem-solving courts, imbued with the broad principles of restorative justice and therapeutic jurisprudence, may prescribe interventions that lead to increased surveillance and social control over the people appearing before the court. ${ }^{61}$ In this vein, James Nolan argues that the concepts of restorative justice and therapeutic jurisprudence can serve to frame coercive state practices (such as arbitrary searches) as therapeutic practices that are for the benefit of the person subject to them. ${ }^{62}$ The court-ordered requirement to access services that is a common outcome of specialized courts may itself lead to increased state surveillance by both the service provider and the justice system. ${ }^{63}$ Beyond the inherent violation of unnecessary state intrusion into people's lives, the increase in interventions can lead to an increased risk of charges for non-compliance with

52 Carolyn Boyes-Watson, "In the Belly of the Beast? Exploring the Dilemmas of State-Sponsored Restorative Justice” (1999) 2:3 Contemporary Justice Rev 261.

Spinak, supra note 44 at 121.

Bowen \& Whitehead, supra note 43 at 29.

Ibid at 30 .

Joel Gross, "The Effects of Net-Widening on Minority and Indigent Drug Offenders: A Critique of Drug Courts" (2010) 10:1 U Maryland LJ Race, Religion, Gender \& Class 161; Boyes-Watson, supra note 52.

Gill McIvor et al, Evaluation of the Airdrie and Hamilton Youth Court Pilots (Edinburgh: Scottish Executive, April 2006) at iv, online: <www.sccjr.ac.uk/wp-content/uploads/2009/02/Evaluation of the Airdrie and -Hamilton youth court pilots..pdf $>$.

Ibid at 16 .

Spinak, supra note 44.

Dandurand \& Vogt, supra note 34 at 14-16.

Bowen \& Whitehead, supra note 43 at 30.

Nolan Jr, supra note 39 at 1556.

Spinak, supra note 44 at 118. 
conditions. ${ }^{64}$ In addition, these conditions can increase the risk of further substantive offences, as inappropriate interventions have been shown to lead to increased recidivism. ${ }^{65}$ Despite the emphasis placed on autonomy and self-determination by therapeutic jurisprudence theory, in practice some problem-solving courts nevertheless exert a paternalistic form of control over people appearing before the court. ${ }^{66}$ This is a particularly troubling concern for Indigenous-oriented courts given the long history of paternalism shown by the Canadian state towards Indigenous peoples. ${ }^{67}$

Finally, many have expressed procedural concerns regarding problem-solving courts, arguing that due process rights of accused may be compromised. One issue arises from the re-orientation of the judge's role from impartial adjudicator to facilitator of rehabilitation. ${ }^{68}$ Nolan has documented the due process concerns that can arise from this new judicial role in the context of drug courts, ${ }^{69}$ describing judges coercing people into treatment, or even sentencing people to jail, ${ }^{70}$ while stating that they are not imposing punishment but rather "helping" deliver therapeutic outcomes. ${ }^{71}$ As Michael Dorf and Jeffrey Fagan state:

\footnotetext{
When the state expressly advocates imprisonment as a means of retribution, incapacitation or deterrence, the judge understands that the interests of the state and of the defendant are antagonistic, and that the judicial function is to give each side a fair hearing. However, when the state proposes treatment backed by threat of punishment for the defendant's own good, the judge may lose sight of the fact that interests remain opposed. ${ }^{72}$
}

This judicial re-orientation may have particularly negative consequences for those who experience systemic discrimination, as judges may no longer act as a potential check on racist state practices but, instead, collaborate with police, prosecutors, and defence lawyers in devising (coercive) therapeutic interventions. ${ }^{73}$

These concerns should be considered in any discussion surrounding the establishment of an Indigenous-oriented court. However, the status quo of the Canadian justice system vis-àvis Indigenous people is clearly unacceptable. The goal must be to devise new court processes that avoid the pitfalls described above. As a general statement, one answer to these concerns is that genuine power must be ceded to Indigenous communities. ${ }^{74} \mathrm{I}$ describe in Part IV some ways in which control over court processes and structure can be exercised by Indigenous communities rather than the Crown, judges, and other agents of the settler

Bowen \& Whitehead, supra note 43 at 29.

Christopher T Lowenkamp \& Edward J Latessa, "Understanding the Risk Principle: How and Why Correctional Interventions Can Harm Low-Risk Offenders" (2004) Topics in Community Corrections 3.

King, supra note 39 at 1541.

See e.g. Mary Ellen Turpel, "Patriarchy and Paternalism: The Legacy of the Canadian State for First Nations Women" (1993) 6 CJWL 174.

Nolan Jr, supra note 39 at 1541.

Ibid.

Ibid at 1544 .

Ibid at 1555 .

Michael C Dorf \& Jeffrey A Fagan, "Problem Solving Courts: From Innovation to Institutionalization" (2003) 40:4 Am Crim L Rev 1501 at 1510.

Spinak, supra note 44 at 126.

See Boyes-Watson, supra note 52 ("[o]nly in partnerships where the community is a more powerful partner, is it possible for the assessment of risks and benefits to be made from a community rather than a system perspective" at 270). I address the, thus far limited, ceding of control to community justice organizations in the British Columbia context, above. 
colonial state. Before addressing these issues, I will describe the historic and ongoing harm of the mainstream Canadian justice in more detail.

\section{FAILURES OF CANADA's Justice System}

\section{A. Historic ANd ONGoing COLONIALISM AND OVERREPRESENTATION}

The shortcomings and injustices of the Canadian legal system in regards to Indigenous people are well-documented. ${ }^{75}$ In short, the justice system is one means by which colonialism wreaks its destructive force on Indigenous peoples and cultures. This is shown most clearly by the stark and growing overrepresentation of Indigenous people in Canada's prisons. In 2014 and 2015, Indigenous people accounted for 26 percent of the adults admitted to provincial and federal prisons, almost nine times higher than the 3 percent of Canadian adults who are Indigenous. ${ }^{76}$

The Royal Commission on Aboriginal Peoples recognized that while socio-economic factors and notions of a "culture clash" are partial explanations for Indigenous overrepresentation in the criminal justice system, the primary cause is colonialism. ${ }^{77}$ The link between colonialism and Indigenous overrepresentation has two related facets. First, Indigenous cultures, communities, and families have been deliberately disrupted by the settler colonial state, often through legal techniques such as the forced relocation and containment of Indigenous people on reserves, the criminalization of cultural practices, and the separation of Indigenous children from their families in Indian Residential Schools and continuing today through child apprehensions. The resulting inter-generational trauma continues to fuel cycles of family instability, addiction and justice system involvement. ${ }^{78}$ Second, systemic and interpersonal racism continues to be present in all aspects of Canada's justice system, ${ }^{79}$ causing Indigenous people to experience disproportionate and unjustified levels of police contact; ${ }^{80}$ a greater likelihood of being denied bail and, thus, more time spent in pre-trial custody; ${ }^{81}$ more and longer prison sentences $;{ }^{82}$ and more time served before being granted parole. ${ }^{83}$

See e.g. Royal Commission on Aboriginal Peoples, Bridging the Cultural Divide: A Report on Aboriginal People and Criminal Justice in Canada (Ottawa: Canada Communication Group, 1996), online: <data2.archives.ca/rcap/pdf/rcap-464.pdf> [RCAP, Bridging the Cultural Divide]; Aboriginal Justice Implementation Commission, Report of the Aboriginal Justice Inquiry of Manitoba (November 1999), online: <www.ajic.mb.ca/volume.html> [Aboriginal Justice, Inquiry of Manitoba].

76 Canada, Department of Justice, "Indigenous Overrepresentation in the Criminal Justice System" (January 2017), online: <www.justice.gc.ca/eng/rp-pr/jr/jf-pf/2017/jan02.html>.

RCAP, Bridging the Cultural Divide, supra note 75 at $46-50$.

Ibid at $39-40$.

Ibid at 39.

Robin T Fitzgerald \& Peter J Carrington, "Disproportionate Minority Contact in Canada: Police and Visible Minority Youth” (2011) 53:4 Can J Criminology \& Criminal Justice 449. RCAP, Bridging the Cultural Divide, supra note 75 at 45.

TRC, Honouring the Truth, supra note 7; Julian Roberts \& Ronald Melchers, "The Incarceration of Aboriginal Offenders: Trends From 1978 to 2001" (2003) 45:2 Can J Criminology \& Criminal Justice 211; Jeff Latimer \& Laura Casey Foss, "The Sentencing of Aboriginal and Non-Aboriginal Youth Under the Young Offenders Act: A Multivariate Analysis" (2005) 47:3 Can J Criminology \& Criminal Justice 481.

83 Public Safety Canada, "Corrections and Conditional Release Statistical Overview” (2016), online: $<$ www.publicsafety.gc.ca/cnt/rsrcs/pblctns/ccrso-2016/index-en.aspx>. 
Though courts have been required to consider the effects of colonialism and the perspectives of Indigenous peoples when sentencing Indigenous offenders as a matter of law since amendments to the Criminal Code in $1996^{84}$ and the Supreme Court of Canada's later decision in Gladue, ${ }^{85}$ there is clear evidence that, as a whole, Canadian courts have largely failed to do so. ${ }^{86}$ In fact, rather than working to ameliorate the overrepresentation of Indigenous people, consideration of Gladue factors ${ }^{87}$ by Canadian courts may have led to more severe sentences. Attention to Indigenous defendants' educational attainment, employment status, and family relations without connecting these to systemic factors can, in some cases, lead to a higher perception of risk. ${ }^{88}$ As Paula Maurutto and Kelly HannahMoffat write, "R. v. Gladue and R. v. Ipeelee have been compared to other seemingly transformative changes in law that superficially appear 'liberating,' but continue to be inherently filtered through a White judicial lens that perpetuates historical power relations." 89 Nevertheless, in the hands of skilled Gladue report writers, and particularly with a dedicated court infrastructure such as in Ontario's Aboriginal Persons (Gladue) Courts, connections can be made between an Indigenous person's experience of colonial harms and their involvement with the justice system, leading to more contextually aware sentencing processes. $^{90}$

Though appropriate incorporation of Gladue factors ${ }^{91}$ into sentencing decisions is an important development, this is, at best, a minor accommodation of Indigenous people by the settler colonial legal system. To truly address the harms wrought by that system, Canadian law must recognize and provide space for existing Indigenous legal systems. As Jonathan Rudin, the director of Aboriginal Legal Service in Toronto, stated in 1997 "it is hard to see how reliance on a legal system that is rooted in the colonial system that has led to the problems faced by Aboriginal people can lead to real change." 92

The necessity of developing Indigenous justice systems was similarly recognized over 20 years ago by the Royal Commission on Aboriginal Peoples ${ }^{93}$ and the same conclusion was reached by the Manitoba Aboriginal Justice Inquiry and the Donald Marshall Inquiry, among others. ${ }^{94}$ The obligation of Canada to create space for Indigenous justice is also enshrined in the United Nations Declaration on the Rights of Indigenous Peoples, ${ }^{95}$ to which Canada is a signatory, particularly in Article $5^{96}$ ("Indigenous peoples have the right to maintain and

An Act to Amend the Criminal Code (sentencing) and Other Acts in Consequence Thereof, SC 1995, c 22 .

Supra note 32 .

The Supreme Court of Canada itself has adverted to this failure in $R v$ Ipeelee, 2012 SCC 13.

Ibid at para 67.

Debra Parkes, "Ipeelee and the Pursuit of Proportionality in a World of Mandatory Minimum Sentences" (2012) 33:3 For the Defence 22; Maurutto \& Hannah-Moffat, "Gladue Courts," supra note 9. Maurutto \& Hannah-Moffat, "Gladue Courts," ibid at 460.

Ibid.

Gladue, supra note 32 at para 67

Jonathan Rudin, "Legal Aid Needs of Aboriginal People in Urban Areas and on Southern Reserves" in Ontario Legal Aid Review, Report of the Ontario Legal Aid Review: A Blueprint For Publicly Funded Legal Services, vol 2 (1997) 441 at 463, online: < archive.org/stream/mag_00007033\#page/440/mode/ 2 up>.

RCAP, Bridging the Cultural Divide, supra note 75.

Aboriginal Justice, Inquiry of Manitoba, supra note 75; T Alexander Hickman, Lawrence A Poitras \& Gregory T Evans, Royal Commission on the Donald Marshall, Jr., Prosecution: Digest of Findings and Recommendations (Nova Scotia, 1989), online: <novascotia.ca/just/marshall_inquiry $>$.

GA Res 61/295, UNGAOR, 61st Sess, Sup No 53, UN Doc A/61/295 (2007), online: <www.un.org/ esa/socdev/unpfii/documents/DRIPS_en.pdf $>$ [UNDRIP]. Ibid, art 5. 
strengthen their distinct political, legal, economic, social and cultural institutions") and Article $34^{97}$ ("Indigenous peoples have the right to promote, develop and maintain their institutional structures and their distinctive customs, spirituality, traditions, procedures, practices and, in the cases where they exist, juridical systems or customs, in accordance with international human rights standards"). ${ }^{98}$ Finally, and more recently, the TRC has called for the "recognition of the rights of Aboriginal communities to develop their own justice systems as part of a larger commitment to Aboriginal self-determination and self-government." 99

The past 20 years has seen a surge in Indigenous-oriented justice programs as hundreds of Indigenous communities across Canada have developed programs through grants issued under the federal government's Aboriginal Justice Strategy (recently renamed the Indigenous Justice Program) ${ }^{100}$ Most of these are located in non-urban Indigenous communities, but there also numerous urban-focused programs. These include services such as victim outreach and post-incarceration reintegration, but many are diversion programs involving sentencing circles, community councils, and other restorative justice practices that incorporate Indigenous principles. While the integration of Indigenous legal principles into the Canadian system is a relatively new development, the principles and processes themselves are not. As Aboriginal Legal Services Toronto state, "the concept of the Community Council is not new ... this is the way justice was delivered in Aboriginal communities in Central and Eastern Canada for centuries before the arrival of Europeans to North America."101

While a survey of diversion programs established under the Aboriginal Justice Strategy is beyond the scope of this article, undoubtedly they have provided many positive impacts for communities. However, these initiatives seem to largely fall within what was described 20 years ago as inadequate for addressing the harms wrought by the colonial legal system: "diversion programs where Indian people are allowed to participate in sentencing panels but not in the determination of guilt and certainly not in determining what the system should look like and what the laws should be within the community." 102

An example of both the positive impacts made by such programs and the limitations caused by the unwillingness of actors within the Canadian justice system to cede ground to Indigenous peoples is shown in the experience of the VATJSS. The program was developed in close consultation with the Indigenous community in Vancouver and appears to have earned the confidence of that community in its 18 years of operation. ${ }^{103}$ In addition to providing housing assistance and other community-oriented services, VATJSS operates a diversion program that accepts referrals from Crown counsel and, through a community council process, creates a healing plan "with the goal of making amends and positively

Ibid, art 34.

Ibid.

TRC, Honouring the Truth, supra note 7 at 228.

100 As of 2017 the Indigenous Justice Program funded " 197 community-based programs that serve over 750 communities": Department of Justice, "Community-Based Justice Fund" (2017), online: <www. justice.gc.ca/eng/fund-fina/acf-fca/ajs-sja/cf-pc/index.html>. Aboriginal Legal Services, "Community Council Background," online: <www.aboriginallegal.ca/ background.html $>$ [Aboriginal Legal Services, "Community Council"].

Donald Auger, "Legal Aid, Aboriginal People, and the Legal Problems Faced by Persons of Aboriginal Descent in Northern Ontario" in Ontario Legal Aid Review, supra note 92, 397 at 420.

103 Ted Palys, "A Programme Evaluation of Vancouver Aboriginal Transformative Justice Service Society (VATJSS)" (2014) at 27-31, online: <www.sfu.ca/ palys/VATJSEvaluation-2014.pdf> [Palys, "VATJSS"]. 
reintegrating the offender into the community." 104 An evaluation of the program published in 2014 stated "numerous indicators affirm that VATJSS is very successful in what it does," including an 82 percent rate of successful healing plan completion and positive feedback from clients, community partners, and community members. ${ }^{105}$ The program, however, has been plagued by unstable funding and is "subject to justice system caprice" as referrals are dependent on the individual decisions of Crown counsel and other justice system personnel. ${ }^{106}$ This resulted in limited referrals and, according to a former Executive Director, VATJSS never was allowed to handle cases where people were likely to receive a jail sentence. ${ }^{107}$ The program evaluation reported a sense among VATJSS staff that "VATJSS and Aboriginal justice often was treated by mainstream justice practitioners as an adjunct to the 'real' justice system that was run by lawyers and judges in courts."108

These issues of perceived legitimacy of VATJSS within the Canadian legal system raises the question of whether Indigenous-oriented courts have a greater potential to provide authority to Indigenous communities in addressing criminal matters. While many existing courts have significant limitations, including the retention of Crown control over who may appear before them, I contend that aspects of these courts provide examples of how more space can be created for Indigenous justice within the confines the settler colonial legal system. Before discussing this potential in Part IV, I first discuss some of the institutional barriers to creating new court models in British Columbia.

\section{B. BRITISH COLUMBIA'S APPROACH TO INDIGENOUS COURTS}

In 2016, British Columbia's Ministry of Justice released its "Specialized Courts Strategy," 109 which "establishes a structured approach for current and future specialized courts that is rooted in validated research, is fiscally responsible, and engages the judiciary, justice system partners and other interested parties." 110 The strategy applies to specialized courts dealing with criminal matters and was created in response to the creation of FNCs and other courts that were "established without a province wide planned, coordinated allocation of limited resources to advance effective justice solutions throughout British Columbia."111 New court initiatives involving the dedication of resources must now be rigorously justified through a "proven business case rationale" 112 and adhere to "best practices"113 identified in the strategy.

While the "Specialized Courts Strategy" system" can have negative consequences for the people involved, it primarily frames the

Vancouver Aboriginal Transformative Justice Services Society, "Services for Aboriginal Youth and Adults: Justice, Housing and More," online: < vatjss.com/services>.

Palys, "VATJSS," supra note 103 at 28.

Ibid at 6.

Ibid at 38 .

Ibid.

Ministry of Justice, "Specialized Courts Strategy," supra note 13.

Ibid at 3 .

Ibid.

Ibid at 15 .

Ibid at 20 .

Ibid. 
value of new courts in terms of their capacity to respond to problems external to courts themselves, problems that are localized in individual "offenders." In the terms of the strategy, the primary metric of effectiveness is the capacity to reduce recidivism. Undoubtedly, this outcome is important to the people involved in Indigenous justice initiatives. VATJSS staff, for example, expressed a desire for better data that could show what they believe is the positive effect of their programs on recidivism levels. ${ }^{115}$ Marion Buller, judge of the New Westminster FNC, has also stated a belief in the court's efficacy in this regard. ${ }^{116}$ While the desire to frame effectiveness in this way may, in part, be conditioned by an institutional outlook that understands reductions in recidivism to be the sine qua non of a worthwhile program, ${ }^{117}$ there can be little doubt that service providers wish to see their clients avoid involvement with the justice system in the future.

Indigenous justice programs, however, can and do provide benefits that go well beyond effects on recidivism. These initiatives can mitigate the harm caused by the colonial justice system in a variety of ways, as I describe in Part IV. In addition, the ceding of authority over justice to Indigenous people is of significant value in itself as a step towards decolonization, something that cannot be recognized within an evaluative framework focused on "offenders." Finally, the principles that animate problem-solving courts are not necessarily intended to be used as a method to reduce recidivism. According to one of its pioneers, the value of restorative justice is in the process itself and its effect on all parties involved, not in its effect on crime rates. ${ }^{118}$ Thus, reduced recidivism is not the only reason to create new specialized courts, nor is it the only valid measure of their success.

Aligning with a focus on measures of recidivism, the "business case" required of a new specialized court must indicate how the court will align with "evidence-based principles." 119 The strategy highlights, in particular, the Risk-Needs-Responsivity (RNR) model as "the most effective way in which to identify and prioritize offenders to make sure they receive appropriate interventions." 120 Developed by Canadian criminologists, ${ }^{121}$ the RNR model adheres to a broad trend of increasing reliance on actuarial risk assessment tools within the criminal justice system. ${ }^{122}$ The RNR model involves assessing risk through formalized instruments that measure various personality and life history factors which, according to the model's proponents, have been empirically demonstrated to increase the likelihood of reoffending. ${ }^{123}$ These include "inappropriate parental monitoring and disciplining," "poor

Palys, "VATJSS," supra note 103 at 5.

Johnson, supra note 9 at 8 .

See Boyes-Watson, supra note 52 at 273 urging a focus on "holistic goals of community participation and empowerment within restorative justice programs" and to "defy the pressure to measure their success by the political yardstick of recidivism."

Zehr, supra note 35.

Ministry of Justice, “Specialized Courts Strategy," supra note 13 at 14.

Ibid.

DA Andrews, James Bonta \& RD Hoge, "Classification for Effective Rehabilitation: Rediscovering Psychology" (1990) 17:1 Criminal Justice \& Behavior 19; James Bonta \& DA Andrews, "Risk-NeedResponsivity Model for Offender Assessment and Rehabilitation" (2007), online: Public Safety Canada $<$ www.publicsafety.gc.ca/cnt/rsrcs/pblctns/rsk-nd-rspnsvty/index-en.aspx $>$.

For a broad discussion and critique of the role of actuarial risk assessment tools within justice systems, see Kelly Hannah-Moffat, “Actuarial Sentencing: An 'Unsettled' Proposition” (2012) 30:2 Justice Q 270.

Bonta \& Andrews, supra note 121 at 5. 
family relationships," substance abuse, "negative attitudes towards the law," and "poor performance" and "low levels of satisfaction" with work or school. ${ }^{124}$

This approach explicitly places the cause of crime within the individual and specifically eschews attention to social context, citing "the demonstrated superior predictive criterion validity of RNR assessments relative to social location variables."125 Instead of the direction in Gladue $e^{126}$ to understand personal and life history factors in terms of the harms of colonialism and as providing the appropriate context to understanding an Indigenous person's circumstances, this model is, in essence, designed to formalize and institutionalize the perception of Gladue factors ${ }^{127}$ as indicators of increased risk and, thereby, to justify more severe sentences for Indigenous people. ${ }^{128}$ Moreover, the RNR model is obviously completely divorced from, and likely firmly at odds with, Indigenous principles of justice and Indigenous law. Requiring new courts to conform with such a model poses a serious risk of subverting any attempt to move away from the settler colonial justice system.

In addition to new court proposals being evaluated through such a justificatory framework, the "Specialized Courts Strategy" 129 requires all specialized courts to be subject to "on-going monitoring and rigorous evaluation to ensure they are meeting objectives and are costeffective." 130 To this end, the creators of the RNR model have developed an actuarial statistical inventory "to assess the degree of adherence to the principles of RNR demonstrated by a program." "131 These requirements serve to place the determination of whether a court is fulfilling its function outside of the community that it is intended to serve and, instead, places control in the hands of experts able to determine whether an initiative is properly adhering to "best practices." This approach denies Indigenous sovereignty over the justice system. While a new Indigenous court should certainly be subject to scrutiny, it should be the scrutiny of the Indigenous community, not the colonial bureaucracy. A broad and deep consultative process led by Indigenous people and involving Indigenous communities would, much more than a "proven business case," help to ensure that any new Indigenous court is supported by and serves the needs of Indigenous people.

Fortunately, there are signs the new provincial government, formed in 2017, will take a different approach from that articulated in the "Specialized Courts Strategy."132 The government has committed to implementing the TRC Calls to Action ${ }^{133}$ and each Cabinet minister's mandate letter includes a direction to "review policies, programs and legislation

Ibid at 6 .

Don A Andrews, James Bonta \& J Stephen Wormith, “The Recent Past and Near Future of Risk and/or Need Assessment" (2006) 52:1 Crime \& Delinquency 7 at 21. Gladue, supra note 32.

Ibid at para 67.

See Toni Williams, "Intersectionality Analysis in the Sentencing of Aboriginal Women in Canada" in Emily Grabham et al, eds, Intersectionality and Beyond: Law, Power and the Politics of Location (New York: Routledge-Cavendish, 2009) 79 at 94. For a discussion of the clash between actuarial logic of risk assessment and Gladue principles, see Kelly Hannah-Moffat \& Paula Maurutto, "Re-Contextualizing Pre-Sentence Reports: Risk and Race" (2010) 12:3 Punishment \& Society 262.

Ministry of Justice, "Specialized Courts Strategy," supra note 13.

Ibid at 13 .

Andrews, Bonta \& Wormith, supra note 125 at 20.

Ministry of Justice, "Specialized Courts Strategy," supra note 13.

Supra note 1. 
to determine how to bring the principles of UNDRIP to action in British Columbia." ${ }^{134}$ While there appears to be severe limits on the degree to which these commitments translate into a departure from colonial policies in regards to Indigenous land, ${ }^{135}$ in the area of justice system reform the government appears ready to cede greater control to Indigenous communities. The province has signed a memorandum of understanding with Indigenous service providers and political organizations to develop a new Indigenous Justice Strategy. ${ }^{136}$ Instead of measurements of recidivism, the strategy will focus on addressing failings of the justice system in regards to Indigenous people, including "[d]ecreasing the overrepresentation of Indigenous people" and "[e]ngagement with Indigenous communities and organizations in a respectful and culturally appropriate manner." 137 The province has asked Indigenous organizations to "take a primary role in the design and eventual delivery of this initiative,"138 including developing the method by which program success will be evaluated. ${ }^{139}$ One possibility emerging from initial consultations is the creation of Indigenous communitycontrolled processes for addressing criminal offences. ${ }^{140}$ In the next section, I discuss the potential of an Indigenous court to realize the goals of Indigenous justice and community control in an urban context.

\section{AN URBAN INDIGENOUS COURT}

In this section, I provide examples of practices and perspectives from existing initiatives that could inform the development of an urban Indigenous court. The harms of colonial justice systems and the overrepresentation of Indigenous peoples in them are not confined to Canada, and Indigenous courts have been developed in a variety of settler colonial states. ${ }^{141}$ Therefore, while I focus on examples derived from the Canadian context, and particularly British Columbia's FNCs and the VATJSS, I also draw from courts in the United States, New Zealand, and Australia. While I contend that many of these examples have the potential to make a court more responsive and effective in addressing the needs of Indigenous people and communities, this is not a list of "best practices." The appropriateness of any court process is dependent on the community in which it takes place and the specific values and needs therein.

Office of the Premier, "Premier and First Nations Leaders Deliver Unified Message Recognizing UN Declaration on the Rights of Indigenous Peoples and TRC Calls to Action" (6 September 2017), online: $<$ news.gov.bc.ca/releases/2017PREM0080-001537>.

135 See for example, the decision to continue construction of the Site C Dam over the opposition of Indigenous peoples whose land the project will destroy: Justin McElroy, "B.C. Government to Go Ahead with Site C Hydroelectric Dam Project," CBC News (11 December 2017), online: <www.cbc.ca/news/ canada/british-columbia/site-c-dam-decision-1.4435939>.

136 British Columbia Ministry of Attorney General, "Province and Aboriginal Justice Council Sign B.C. Indigenous Justice Strategy MOU" (7 September 2017), online: <news.gov.bc.ca/releases/2017 AG0020-001548>.

137 "Memorandum of Understanding Regarding the Development of an Indigenous Justice Strategy Between: The Ministry of Attorney General, the Ministry of Public Safety and Solicitor General and the British Columbia Aboriginal Justice Council,” online: <nccabc.ca/wp-content/uploads/2016/06/ ScanDoc_20170908_103229.pdf>.

138 Letter from David Eby to Mr. Douglas White III, President of Native Courtworkers and Counselling Association of British Columbia, and Celeste Haldane, Chair of the Board of Directors of Legal Services Society (16 January 2018), on file with author.

Ibid.

Personal communication with participant in consultation process.

Johnson \& Sarra, supra note 49. 


\section{A. FRAMEWORK FOR INDIGENOUS PARTICIPATION AND CONTROL}

The participation of Indigenous people and communities in the establishment of a court, its continuing oversight, and in court processes themselves would be an important part of ensuring that a court works in the interests of the Indigenous community. In courts established by specific Indigenous nations, this is perhaps more straightforward as, in the case of the Teslin Tlingit Peacemaker Court or the Akwesasne Court, for example, the Indigenous self-government exercises oversight over the court process. ${ }^{142}$ Though it is less clear in the context of an urban court who could exercise such authority, the formation of VATJSS provides one example of a process in which Indigenous organizations played a leading role in establishing a justice program that appears to have strong support from the Indigenous community. ${ }^{143}$ An Aboriginal Caucus constituted by members of Indigenous organizations developed VATJSS's policies and approach to restorative justice through extensive consultation with Indigenous communities in the Vancouver area. ${ }^{144}$ These included formal consultations with local Elders and a Community Forum and Feast, both conducted at Vancouver's Aboriginal Friendship Centre. ${ }^{145}$ These consultations confirmed support for the program among Indigenous people in Vancouver, provided detailed guidance on the program's processes and structure, and, centrally, worked to ensure the program was "Aboriginally driven and controlled." 146 As the Executive Director of VATJSS has stated, "[i]t's not up to us to decide what 'Aboriginal justice' means in our community; it's our community that decides this."147

Ongoing oversight by Indigenous communities would also ensure that a court continues to be controlled by and responds to the needs of Indigenous peoples. The caucus model involving representatives of Indigenous organizations could be kept in place after initial program development in order to provide continuing oversight and a continuing relationship with the Indigenous community. This is the recommendation of a comprehensive report on Tribal Healing to Wellness Courts in the United States, which states that those responsible for planning and implementing a new court should remain present in an oversight capacity, providing stability and ensuring the court fulfills its intended purposes. ${ }^{148}$ The development and ongoing oversight of Cknúcwentn First Nations Court, which sits in Secwepemc territory, demonstrates such a process. The court was developed through the advocacy work of Cree/Secwepemc lawyer Linda Thomas who chairs an Aboriginal Justice Council made up of representatives of Indigenous justice organizations and service providers, including Secwepemc organizations Tk'emlups Adult Justice and Secwepemc Community Justice, as well as Crown and government representatives. ${ }^{149}$ The Council oversees "funding, court scheduling, recruiting of Elders and formalizing their activities through terms of reference

Teslin Tlingit Council, "Peacemaker Court," supra note 8; Akwesasne Court Law, supra note 4.

Ted Palys, "Vancouver's Aboriginal Restorative Justice Program: The Challenges Ahead" (1999) 3:1

Aboriginal Justice Bulletin 2 at 3 [Palys, "Aboriginal Restorative Justice"]; Dorward, supra note 27.

Dorward, ibid.

Ibid.

Ibid at 65 .

Quoted in Palys, "VATJSS," supra note 103 at 21.

Joseph Thomas Flies-Away et al, Tribal Healing to Wellness Courts: The Key Components (Hollywood: Tribal Law and Policy Institute, 2014) at 3, online: <www.wellnesscourts.org/files/Tribal\%20Healing $\% 20$ to $\% 20$ Wellness $\% 20$ Courts\%20The $\% 20$ Key\%20Components.pdf $>$. 
and operating manuals," ${ }^{150}$ and the name of the court itself, meaning "the place where help is given," was given by local Secwepemc Elders. ${ }^{151}$

In the court process, the presence of Elders is a common feature of many Indigenousoriented courts. ${ }^{152}$ In British Columbia's FNCs, for example, Elders participate along with other community members, lawyers, and justice system representatives in a judge-led discussion that crafts a healing plan for the person appearing before the court. ${ }^{153} \mathrm{In}$ addition to Elders, other representatives of local Indigenous communities are involved in some court proceedings. For example, at the North Vancouver FNC, justice workers from the TsleilWaututh and Squamish peoples represent those community's interests. ${ }^{154}$ In addition, circle sentencing processes that involve significant roles for Indigenous community members have been employed by mainstream Canadian courts, particularly Yukon and Saskatchewan circuit courts, in response to pressure from Indigenous communities for greater participation. ${ }^{155}$

An important question in all these court processes that provide for the participation of Elders and Indigenous communities is to what degree these participants exercise control over outcomes. A detailed review of circle sentencing practices in mainstream courts found that, while they do accord decision-making authority to Indigenous communities in some cases, this is dependent upon a judicial attitude of deference towards the opinions of community members. ${ }^{156}$ In these sentencing circles, as with British Columbia's FNCs, all formal authority is retained by the judge. In contrast, diversion programs such as VATJSS involve decision-making by Indigenous community representatives, ${ }^{157}$ but their ambit is often severely circumscribed by Crown decisions to refer only people who have committed very minor offences. ${ }^{158}$ An urban court that employed community councils or circle processes and provided them with formal decision-making power, could allow for Indigenous communityled responses to more serious offences.

In addition to questions regarding the authority of Indigenous participants, there are practical issues regarding the participation of a person's home community if it is located far from the urban area where an offence has occurred. One solution could be found in British Columbia's legislative scheme governing child protection, which provides for Indigenous communities to participate in child protection hearings through the relevant First Nation band government or through an Indigenous organization chosen by the parent or child. ${ }^{159}$ A mere invitation to communities to participate, however, would likely be insufficient. According to Grand Chief Ed John's report on Indigenous child welfare, ${ }^{160}$ adequate and clear

\footnotetext{
150 Dandurand \& Vogt, ibid at 7.

Johnson, supra note 9 at 8 [emphasis in original].

See e.g. the Tsuu T'ina Peacemakers Court and British Columbia's FNCs: ibid.

Johnson, ibid.

Ibid at 8 .

McNamara, supra note 9.

Ibid.

See e.g. Palys, "VATJSS," supra note 103; Toronto Community Council: Aboriginal Legal Services, "Community Council," supra note 101.

See discussion, above.

159 Child, Family and Community Service Act, RSBC 1996, C 46, s 39(1)(c); Child, Family and Community Service Regulation, BC Reg 527/95, s 11, Schedule 1, Schedule 2.

160 Ed John, Indigenous Resilience, Connectedness and Reunification - From Root Causes to Root Solutions: A Report on Indigenous Child Welfare in British Columbia (2016), online: $<$ fns.bc.ca/wpcontent/uploads/2017/01/Final-Report-of-Grand-Chief-Ed-John-re-Indig-Child-Welfare-in-BCNovember-2016.pdf $>$.
} 
information regarding child protection proceedings is often not provided and many First Nations do not have sufficient financial resources to retain counsel to represent the Indigenous community's perspective. ${ }^{161}$ In the context of an urban court, the enactment of Ed John's recommendations of improved information dissemination and sufficient funding to facilitate participation, ${ }^{162}$ could allow for an Indigenous defendant's own community to play a significant role in court processes.

The involvement of Elders and Indigenous communities is a central principle of restorative justice and is important to many Indigenous cultures' approach to dispute resolution. However, in some urban Indigenous-oriented courts, a greater role has also been accorded for police, probation officers, and other institutions ${ }^{163}$ that have been major contributors to the justice system's harmful effect on Indigenous people. The presence and potential influence of these institutional actors within a court process may detract from an Indigenous-led process and may also raise due process concerns, as I discuss in Part IV.H. In addition, their presence may not be a culturally appropriate response, particularly for the many Indigenous people who have had negative experiences with these agents of settler colonial state authority. Therefore, any role for non-Indigenous institutions within the court process should be carefully considered and should be subject to Indigenous community approval.

\section{B. Indigenous Legal Principles}

Indigenous legal principles are the traditional laws of this territory. I do not purport to delve into the complexities and particularities of various Indigenous legal systems, nor the issues involved in revitalizing and applying these laws through what is now the mainstream justice system. ${ }^{164}$ Rather, I briefly consider how Indigenous-oriented courts have approached Indigenous legal principles and the specific issues raised by the urban context.

Common to most Indigenous legal traditions is an orientation towards what could be considered restorative justice principles. ${ }^{165}$ These principles are emphasized in most Indigenous-oriented courts in processes that provide for wide community participation and in outcomes that focus on repairing relationships within the community rather than punishing offenders. ${ }^{166}$ Community participation commonly takes place within what is known as a "circle" process where "individuals are invited to sit in a circle with the accused and discuss together what sentences should be imposed." ${ }^{\prime 67}$ The Royal Commission describes these processes as "a decision to return, in a fashion, to the way justice was done before the arrival

The Hon Judge Marion Buller Bennett, "First Nations Court of British Columbia: Walking the Healing Path" Bar Talk 22:3 (June 2010) 14, online: <issuu.com/cbabc/docs/bartalk $0610>$.

For a detailed consideration of the practicalities of analyzing and applying Indigenous law, see Friedland, supra note 8.

Flies-Away \& Garrow, supra note 48; Johnson \& Sarra, supra note 49.

Johnson, supra note 9; Karen L Whonnock, "A Tale of Two Courts: The New Westminster First Nations Court and the Colville Tribal Court" (2011) 44:1 UBC L Rev 99.

RCAP, Bridging the Cultural Divide, supra note 75 at 110. 
of the non-Aboriginal legal system." "168 However, while many Indigenous communities consider circle processes to be an aspect of their justice traditions, not all do. ${ }^{169}$

Indigenous-oriented courts generally mandate outcomes that promote taking responsibility, healing, and reintegrating those who have committed offences back into the community. For example, the New Westminster FNC delivers sentences in the form of "healing plans" that "go to the root cause of the offending behaviour and provide the person with the assistance that she or he needs." $" 170$ This assistance often takes the form of referrals to counselling, health programs, and Indigenous organizations in the community. ${ }^{171}$ The Colville Tribal Court also takes a "healing and restorative justice" approach to sentencing, often with the aim of providing the person with a positive way to contribute to his or her community and culture.

In the urban context there are difficult questions regarding which Indigenous principles should be incorporated into an Indigenous-oriented court. Canada's urban areas contain diverse Indigenous populations ${ }^{172}$ and, as the TRC states, "Aboriginal forms of justice may be as diverse as Canada's Aboriginal peoples themselves." accepted that most Indigenous nations prioritize healing, ${ }^{174}$ the approach to these broad principles varies widely. In the consultations that led to the establishment of VATJSS, Elders emphasized the need to ensure the diversity of values and practices among Indigenous people was recognized and respected. ${ }^{175}$ As one Elder stated, the proposed program "cannot fall into the trap of Pan-Canadian Indianism."176 Instead, the Elders called for ascertaining the commonalities between nations and, then, incorporating specific features of various traditions where appropriate. These specific principles may be more effective in responding to harms and promoting healing. In consultations with the Cree community of Aseniwuche Winewak to inform the development of an Indigenous court, Hadley Friedland found:

It is significant that every participant wanted a court process that used Cree legal principles, and that their primary reason was it's perceived efficacy relative to the current mainstream justice system. While people did like the idea of it being their own generally, they also clearly saw their own laws and ways of responding to dangerous or harmful actions as more effective in helping people and creating and maintaining safe healthy and peaceful communities. ${ }^{177}$

Ibid.

McNamara, supra note 9. For a critique of reductionist and homogenizing views of Indigenous cultures in relation to circles, see Marilyn Dumont, A Really Good Brown Girl (London, Ont: Brick Books, 1996) (" $\mathrm{t}]$ here it is again, the circle, that goddamned circle, as if we thought in circles, judged things on the merit of their circularity" at 57).

Bennett, supra note 163.

Ibid.

In Vancouver, for example, 36 different Indigenous languages were identified as mother tongues in the 2016 census: see Statistics Canada, Census Profile, 2016 Census, Vancouver [Census metropolitan area], British Columbia and British Columbia [Province], Catalogue No 98-316-X2016001 (Ottawa: Statistics Canada, 2017), online: <https://www12.statcan.gc.ca/census-recensement/2016/dp-pd/prof/ details/page.cfm?Lang $=$ E\&Geo1 $=$ CMACA\&Code $1=933 \&$ Geo2 $=$ PR\&Code $2=59 \&$ Data $=$ Count\&Sea rchType $=$ Begins $\&$ SearchPR $=01 \& B 1=A 1 l \& T A B I D=1>$.

TRC, Honouring the Truth, supra note 7 at 228.

Flies-Away \& Garrow, supra note 48 at 411; Johnson \& Sarra, supra note 49; Palys, "Aboriginal Restorative Justice," supra note 143.

Dorward, supra note 27 at 57.

Ibid.

Friedland, supra note 8 at 218 [emphasis in original]. 
In many cultures, Elders have the responsibility of resolving disputes and function as "the embodiment of Indigenous law." 178 Therefore, the incorporation of specific Indigenous legal principles could perhaps be facilitated in an urban court through an appropriate process and sufficient resources to allow for meaningful participation of Elders from the defendant's community in court processes. An example of a formal process for accessing Elders' legal knowledge is provided by the Colville Tribal Court in the United States, in which a panel of Elders is sometimes constituted in order to determine issues of Indigenous law. ${ }^{179}$ In addition to the Indigenous legal principles of a defendant's own culture, the principles that are Indigenous to the territory where the court sits should also be given a prominent role. To ignore these principles would be to participate in the attempted erasure of specific Indigenous nations' sovereignty over urban land. ${ }^{180}$ The strong role for Secwepemc Elders and organizations within the Cknúcwentn First Nations Court ${ }^{181}$ provides one example of how a specific nation's sovereignty can be recognized in an urban court.

Beyond the varied approaches to restorative justice principles, Indigenous traditions and conceptions of justice cannot be reduced to simply a focus on "healing." Friedland points out that a core function of any legal system is to respond to dangerous and violent situations that, of necessity, require the use of coercive force. ${ }^{182}$ Equating Indigenous justice with healing creates the impression that serious offences cannot be addressed through Indigenous legal principles. ${ }^{183}$ Many cultures traditionally mandated severe consequences for serious offences, including the death penalty for sexual violations. ${ }^{184}$ This raises the question of how to incorporate Indigenous principles of justice without filtering these through settler colonial notions of acceptability. ${ }^{185}$

One possible answer lies in UNDRIP ${ }^{186}$ which provides for recognition of Indigenous peoples' "customs, traditions, rules and legal systems of the indigenous peoples" 187 and makes these "subject only to such limitations as are determined by law and in accordance with international human rights obligations." "188 This is certainly not the only possible approach and may unduly privilege Western human rights discourses over Indigenous norms. However, this is one authoritative statement that provides a starting point of how to reconcile Indigenous law with what is currently possible within the bounds of Canadian institutions. As with all aspects of an Indigenous-oriented court, these issues must be resolved by Indigenous peoples and communities themselves.

178 Johnson, supra note 9 at 1.

179 Whonnock, supra note 166.

180 See Nicholas K Blomley, Unsettling the City: Urban Land and the Politics of Property (New York: Routledge, 2004).

Dandurand \& Vogt, supra note 34 at 7.

Friedland, supra note 8 at 218.

See Val Napoleon \& Hadley Friedland, "Indigenous Legal Traditions: Roots to Renaissance” in Markus D Dubber \& Tatjana Hörnle, eds, The Oxford Handbook of Criminal Law (Oxford: Oxford University Press, 2014) at 237-38.

184 Sarah Deer, "Decolonizing Rape Law: A Native Feminist Synthesis of Safety and Sovereignty" (2009) 24:2 Wicazo Sa Rev 149 at 157; Sarah Hunt, "Violence, Law and the Everyday Politics of Recognition: Comments on Glen Coulthard's Red Skin, White Masks" (Delivered at Native American and Indigenous Studies Association Conference, Washington, DC, 6 June 2015), online: <archive.criticism.english. illinois.edu/2015\%20Fall\%20Pages/MCT\%202015\%20READINGS/10.20\%20Indigenous\%20Studi es\%20(Byrd)/Hunt $\% 20-\% 20$ Violence $\% 20$ Law $\% 20$ and $\% 20$ Everyday $\% 20$ Politics.pdf $>$. 


\section{Stays Rather Than Convictions}

In some Indigenous-oriented courts healing plans or other restorative approaches comprise part of the sentence given to a person after a conviction or a guilty plea. ${ }^{189}$ However, other courts allow, at least in some cases, for the avoidance of criminal convictions, with charges stayed upon successful completion of court imposed conditions. ${ }^{190}$ The latter approach seems to provide significant added benefits in addressing Indigenous overrepresentation in the justice system and, more generally, the harms caused by that system to Indigenous people. Criminal records themselves cause significant harm, firstly, by creating the conditions for more severe sentences if a person is charged with an offence in the future. This has clear negative individual consequences and can contribute to a "snowball effect" where prior convictions increase the likelihood of Indigenous people receiving jail sentences. ${ }^{191}$ Thus, even where no jail is imposed, convictions contribute to the overrepresentation of Indigenous people in prisons. Secondly, criminal records carry stigma and contribute to the marginalization of those subject to them. Employment opportunities are significantly curtailed as many jobs require criminal record checks ${ }^{192}$ and employers are legally permitted to discriminate against those with criminal records if the conviction is not "unrelated" to the employment. ${ }^{193}$ In addition, finding housing is made more difficult as landlords can, without restriction, discriminate against those with criminal records. ${ }^{194}$

\section{Culturally Appropriate Processes}

Indigenous-oriented courts often explicitly aim to create more culturally appropriate processes for Indigenous people and communities. ${ }^{195}$ For example, many incorporate ceremony into court proceedings. The Rangatahi Courts in New Zealand/Aotearoa, for example, begin with a powhiri, "a ritual ceremony of welcome," in which the Māori hosts and visitors exchange speeches and songs and all of those involved in the process introduce themselves. ${ }^{196}$ In British Columbia's FNCs and the Tsuu T'ina Peacemakers Court in Calgary, smudging ceremonies are performed before the court session begins, involving all who wish to participate. ${ }^{197}$

For example, most of British Columbia's First Nations Courts: Dandurand \& Vogt, supra note 34; Colville Tribal Court: Whonnock, supra note 166.

For example, the New Westminster FNC: Dandurand \& Vogt, ibid at 4.

RCAP, Bridging the Cultural Divide, supra note 75 at 46.

A criminal record check is legally required for work with vulnerable persons: Criminal Records Review Act, RSBC 1996, c-86, s 8; employers may also make criminal record checks a condition of employment as it "is reasonable for the purposes of establishing, managing or terminating an employment relationship between the organization and the individual": Personal Information Protection Act, SBC 2003, c-63, s 13(2)(b). See also the interpretation of this legislation in Order P07-01, Office of the Information and Privacy Commissioner at paras 56-57, online: <www.oipc.bc.ca/ orders/OrderP0701.pdf>.

Human Rights Code, RSBC 1996, c-210, s 13(1)(b); the test for what is related to employment is set out in Woodward Stores (British Columbia) Ltd v McCartney, [1983] 145 DLR (3d) 193 at para 9 (BCSC). See Human Rights Code, ibid, s 10(1)(b) which does not enumerate criminal convictions as a prohibited ground of discrimination for rejecting tenants.

Dandurand \& Vogt, supra note 34 at 3.

The Hon Judge Heemi Taumaunu, Ngāti Pōrou \& Ngāi Tahu, "Rangatahi Courts of Aotearoa/New Zealand - An Update" (2013) 22 New Zealand Law Society Continuing Legal Education Criminal Law Symposium 70.

Bennett, supra note 163; Brent Scout, "Inside the Aboriginal Courtroom in the Calgary Courts Centre," Avenue Calgary (16 January 2017), online: $<$ www.avenuecalgary.com/City-Life/Inside-the-AboriginalCourtroom-in-the-Calgary-Courts-Centre>. 
The Tsuu T'ina Peacemakers Court also provides an example of a physical space that incorporates culturally appropriate features, facilitating ceremony and other culturally appropriate processes. The courtroom was designed in close collaboration with representatives of the Tsuu T'ina as well as Elders and community members of other Indigenous communities. ${ }^{198}$ The result was a design that emulates a teepee's structure, including a circular shape, central hearth, pole motifs on the walls and ceiling, and ventilation to allow sweetgrass smudging. ${ }^{199}$ The importance of the teepee to Blackfoot culture, and its facilitation of the circle process, was described by Reg Crowshoe, a former chief of the Piikani Nation:

The circle model and teepee speak to governance, or Aakaak'tsimaan, in terms of Blackfoot cultural values and practicality... The teepee design perfectly meets the needs of our traditional society. For example, the circular shape is constructive for face-to-face communication by promoting a sense of equity and participation and consensus in discussions and decision-making. There is nowhere to hide in a circle. ${ }^{200}$

Culturally appropriate processes can also include ensuring language accessibility. Australia's Koori courts in Australia, for example, mandate a "plain English" requirement so that participants can better understand the legal process. ${ }^{201}$ However, English may not be the appropriate language for all communities and people. Beyond translation, the conduct of court proceedings in Indigenous languages, where feasible and appropriate, could increase the accessibility of the process for some people appearing before the court. This practice has been adopted in some Canadian courts, including a Cree-speaking provincial circuit court in Saskatchewan that conducts proceedings in either English or Cree according to the choice of the person before the court. ${ }^{202}$ Given that Indigenous legal traditions and principles are deeply tied to Indigenous languages, ${ }^{203}$ the use of these languages may assist in the incorporation of these principles into a court process.

In addition to instituting culturally appropriate processes, some Indigenous courts have made reconnection with culture an aspect of healing plans. The Colville Tribal Court, for example, may direct a person to research his or her own culture and report the findings to the court. ${ }^{204}$ Rangatahi Courts in New Zealand/Aotearoa similarly develop plans for youth that involve re-connecting with their Indigenous culture and language. Judge Heemi Taumaunu describes the process as follows:

Because many of the young people who appear in Youth Court have lost touch with their sense of identity as Māori, emphasis is placed on the young person learning who they are and where they are from, and learning significant aspects of their Māori tribal history. This is approached by expecting each young person who appears in the Rangatahi Court to learn a pepeha (a traditional tribal saying) and a mihi (a greeting in the Māori language). Many of the young people who appear have never spoken te reo Māori prior to their

\section{Scout, ibid.}

199 Ibid; Johnson, supra note 9 at 6-7.

$200 \quad$ As quoted in Scout, ibid.

201 Magistrates' Court of Victoria, “Koori Courts, Information for legal Representatives,” online: <www . magistratescourt.vic.gov.au/sites/default/files/Koori\%20Court\%20-\%20Information\%20for $\% 20$ Legal\%20Representatives.pdf $>$.

202 Johnson, supra note 9 at 7.

203 Borrows, supra note 26.

204 Whonnock, supra note 166. 
appearance in the Rangatahi Court and their efforts can result in an intense personal journey of discovery. This emphasis on knowing "who you are, and, where you are from" draws on traditional Māori beliefs based on whakapapa (genealogy) and whakawhanaungatanga (making connections and relationships). ${ }^{205}$

Disconnection from culture and community is, unfortunately, common for Indigenous people involved with settler colonial state justice systems. For example, 45 percent of clientele referred to VATJSS in Vancouver reported no connection with any Indigenous community. ${ }^{206}$ Thus, the fostering of increased cultural connection could be an appropriate part of healing plans prescribed by an urban court.

An emphasis on culturally appropriate processes may also lead to a reduced focus on other outcomes, such as the efficient use of court time and the speed at which files move through the system, outcomes which have often been a central concern of settler colonial courts. At the New Westminster FNC, for example, Judge Marion Buller states that " $[\mathrm{t}]$ he discussion stops only when everyone has said all that they need to say." ${ }^{207}$ New Zealand/Aotearoa's Rangatahi youth courts devote significant court time to ceremony, emphasizing a culturally appropriate process rather than "efficiency." ${ }^{208}$ Further, bringing the matter to court can be delayed for long periods in order to allow for healing and restorative processes to take place: " $[t]$ he longer the entry of a young person into the Youth Court can be delayed, the higher the likelihood of that young person remaining out of the Youth Court altogether." ${ }^{209}$ This is in contrast to non-Indigenous specialized courts such as Vancouver's Downtown Community Court that emphasize quick disposition of matters. ${ }^{210}$

\section{E. Contextual Understanding OF THE IMPACTS OF COLONIALISM}

Numerous Indigenous-oriented courts have taken measures to ensure that judges, Crown, defence, and others involved in the court process have the capacity to contextualize the individual experiences of Indigenous people. The importance of judges, in particular, having an understanding of the effects of colonialism on Indigenous people was highlighted by Grand Chief Ed John, who called for "[1]imiting the number of judges who can oversee proceedings that involve Indigenous children to those who have undergone education or training related to intergenerational trauma." 211 To this end, Ontario's Aboriginal Persons (Gladue $)^{212}$ Courts were explicitly established in order to better incorporate an understanding of the impacts of colonialism into sentencing decisions. ${ }^{213}$ Most of the judges, lawyers, and staff who are involved in the court have had training in these issues. ${ }^{214}$ Nevertheless, Paula

Taumaunu, Pōrou \& Tahu, supra note 196.

Palys, "VATJSS," supra note 103 at 18.

Bennett, supra note 163.

Taumaunu, Pōrou \& Tahu, supra note 196.

Ibid.

British Columbia Ministry of Justice, "Report From the DCC Executive Board on the Final Evaluation of the Downtown Community Court" (2013) at 6, online: <www.provincialcourt.bc.ca/downloads/dcc/ DCCEvaluation_ExecutiveBoard.pdf $>$ [Ministry of Justice, "Report from the DCC Executive Board"]. Ibid.

Gladue, supra note 32.

Maurutto \& Hannah-Moffat, "Gladue Courts," supra note 9.

Jonathan Rudin, "A Court of Our Own: More on the Gladue Courts" (2006), online: Nishnawbe-Aski Legal Services Corporation <www.nanlegal.on.ca/upload/documents/legal-articles/a-court-of-our-own--more-on-gladue-courts.pdf $>$. 
Maurutto and Kelly Hannah-Moffat's detailed study of Gladue Courts found that trained Gladue report writers were more effective at linking the trauma and disadvantage caused by colonialism to the commission of specific offences and, thereby, eliciting sentences more in line with the principles expressed in Gladue. ${ }^{215}$

The impact of a more nuanced and detailed understanding of the circumstances that led people to commit offences was demonstrated by a British Columbia Legal Services Society study, which found that Indigenous people who had the benefit of a Gladue report received fewer prison sentences and, when jail was imposed, much shorter sentences than a comparator group. ${ }^{216}$ An urban Indigenous court could ensure that mechanisms were in place to foster an appropriate contextual understanding of the circumstances of all people appearing before the court. This could include training for judges and other court personnel, broad funding for Gladue reports, and the full-time employment of caseworkers to produce them, a practice already occurring in Ontario. ${ }^{217}$

\section{F. Anti-COLONIAL Normative Framework}

An important question for defining the approach of an Indigenous court is how it would address violations of Canadian law that are committed for the purpose of advancing Indigenous sovereignty. The Akwesasne Court demonstrates one possible approach by requiring that prospective Justices not have a serious criminal record, with an exception for "offenses pertaining to preservation of community or native rights." ${ }^{218}$ This clearly indicates that not all violations of settler colonial law, even serious ones, are to be regarded by the court as morally blameworthy. While the vast majority of offences dealt with by Canadian courts are not directly motivated by decolonial politics, the privileging of Indigenous culture and sovereignty, rather than an uncritical acceptance of settler colonial legal norms, would be an important principle to establish. Further, the acts that can be seen as resisting colonialism should perhaps not be construed too narrowly. Barkaskas and Buhler describe the stories of Indigenous people's interactions with the legal system as "resistance narratives" that have significant political implications:

These resistance narratives work to undo the notion of the natural Canadian post-settler society. The lived traumas and triumphs of Indigenous peoples in their historical and ongoing resistance to colonialism and in their embodied experiences of displacement actively undermine the legitimacy of the Canadian state and resist the possibility of Canada as a post-settler society where meaningful reconciliation is possible without decolonization and Indigenization. Drawn from individual stories is a broader collective history of existence and survival that is directly linked to self-determination and sovereignty. ${ }^{219}$

Gladue $^{220}$ has already established that the degree of culpability should be considered with reference to how the effects of colonialism have contributed to bringing a person before the

Maurutto \& Hannah-Moffat, "Gladue Courts," supra note 9; Gladue, supra note 32.

Legal Services Society, "Gladue Report Disbursement: Final Evaluation Report”(2013), online: <www. lss.bc.ca/assets/aboutUs/reports/aboriginalServices/gladueReportDisbursementEvaluationJune2013. pdf $>$.

Ibid at 73 .

Akwesasne Court Law, supra note 4, s 4.16(f).

Barkaskas \& Buhler, supra note 30 at 17.

Supra note 32. 
court. Extending this principle to include not only a consideration of the social disadvantage and loss of culture created by colonialism but also the active resistance to these ongoing effects would be a significant indication of a court's orientation toward supporting Indigenous peoples' self-determination.

\section{G. Indigenous COMMUNity CONTROL OVER Who APPEARS BEFORE THE COURT}

Though there are institutional intricacies in precisely why and how Indigenous people are referred to specialized courts and diversion programs, almost all require Crown approval in order to exercise jurisdiction. ${ }^{221}$ Thus, despite many of these programs aiming to provide for Indigenous "control" over justice, that control is at the discretion of Crown. As an evaluation of VATJSS stated:

A major difficulty with this arrangement is that it leaves the control of who is deemed "appropriate" for Aboriginal programming in the hands of the very system that has been chastised on so many different occasions for its handling of Aboriginal people, and places them within a definitional framework and procedural timetable that does not necessarily accord with how an Aboriginal justice system would proceed. $^{222}$

The report pointedly states that this is "a policy that is neither respectful nor mindful of the Aboriginal community." ${ }^{223}$ In addition, despite protocol agreements that create a framework for Crown decisions to refer individuals to a particular program, ${ }^{224}$ individual preferences and beliefs inevitably play a large part in determining who can access Indigenous justice. ${ }^{25}$

Crown decisions are also not made public and are not reviewable by appellate courts, ${ }^{226}$ resulting in a lack of transparency regarding why certain people are able to access Indigenous courts or diversion programs and others are not. The opacity of these decisions is demonstrated by a government-commissioned report on British Columbia's FNCs, which concluded

there is no data that would allow one to document who is involved in a decision to refer a case to a FNC, the criteria actually used to make that decision, or the reasons behind a decision not to refer certain cases to an FNC. Our observations suggest that the criteria may indeed vary from one FNC to another, and that they have evolved over time. $^{227}$

Even between British Columbia's First Nations Courts, the precise mechanism by which accused people are referred to these courts varies, and is, in many ways, unclear: Dandurand \& Vogt, supra note 34. Nevertheless, it is evident that the Crown retains the right to refuse to refer accused to these and other Indigenous-focus courts or to diversion programs. To my knowledge, the one urban specialized court in Canada that exercises automatic jurisdiction is Vancouver's Downtown Community Court. Palys, "VATJSS," supra note 103 at 35. Ibid.

See e.g. Aboriginal Legal Services, "Protocol Between Aboriginal Legal Services of Toronto and the Toronto Crown Attorney's Office," online: <www.aboriginallegal.ca/protocols-with-the-crown.html $>$ [Aboriginal Legal Services, "Protocol"].

Palys, "Aboriginal Restorative Justice," supra note 143; Palys, "VATJSS," supra note 103 at 35, 37-38. Parkes, supra note 88.

Dandurand \& Vogt, supra note 34 at 14. 
Clearly, Crown discretion to elect to not proceed with charges when it is not in the public interest to do so should not be interfered with. However, it should not be necessary for Crown to use that discretion for Indigenous people to access Indigenous justice. Vancouver's Downtown Community Court, in contrast to British Columbia's FNC's, automatically exercises jurisdiction for anyone charged with certain categories of offences within a defined geographic area. An urban Indigenous-oriented court could have similar "default jurisdiction" for Indigenous people, subject to the accused electing to proceed in the mainstream court system instead. ${ }^{228}$ Alternatively, a committee made up of representatives from Indigenous communities could have decision-making authority over who is admitted to the court. This is the framework in the judicially-led circle sentencing processes in Saskatchewan and the Yukon, though judicial approval is also required. ${ }^{229}$

In the consultations that led to the establishment of VATJSS, Elders expressed the conviction that the Indigenous community itself should determine who the program serves and that it should have the capacity to serve people who have committed serious offences. ${ }^{230}$ The Aboriginal Caucus, however, agreed to initially allow for Crown discretion to determine referrals and to limit the program's ambit to minor offences with the expectation that, as the project matured, the Indigenous community would assume greater control. ${ }^{231}$ In the result, that control was never ceded:

In retrospect, the die was cast for VATJSS when the Aboriginal community of Vancouver trusted what they were told by federal and provincial members of the Steering Committee in 1998-1999, i.e., that their placement under 'Alternative Measures' and limitations with respect to the charges and offenders they would be able to deal with were the first step in what would be an evolving relationship. ${ }^{232}$

Firmly establishing mechanisms for Indigenous community control over who appears before a court at the outset could avoid the instantiation of Crown discretion as the status quo.

\section{H. Protection of Due Process Rights}

The protection of an accused's due process rights, both in the process by which a person appears before a court and in the procedures of the court itself, are important for ensuring that Indigenous people are adequately protected from the negative consequences inherent in a criminal court proceeding. Many programs take steps to ensure that Indigenous accused are not inappropriately pushed into accepting responsibility. For example, referrals to the Toronto Community Council program are screened by duty counsel for potential defences on the merits. ${ }^{233}$ Nevertheless, specialized courts tend to generate concerns that incentives related to participating will encourage more people to relinquish their rights in order to access the program, particularly when a guilty plea is a condition of entry. ${ }^{234}$ Currently, at

Palys, "VATJSS," supra note 103.

McNamara, supra note 9; Barry Stuart, "Building Community Justice Partnerships: Community Peacemaking Circles" (1997), online: Department of Justice < publications.gc.ca/collections/collection 2009/justice/J22-12-1997E.pdf>.

Dorward, supra note 27 at 58

Palys, "Aboriginal Restorative Justice," supra note 143.

Palys, "VATJSS," supra note 103 at 37.

Aboriginal Legal Services, "Protocol," supra note 224.

See Flies-Away et al, supra note 148 at 8. 
least two of British Columbia's FNCs require guilty pleas in order to be sentenced by the court. $^{235}$

Though taking responsibility and acknowledging wrongdoing is an important part of restorative justice principles and an important factor for many Indigenous communities in deciding whether to accept a person into Indigenous-led justice programs, ${ }^{236}$ the possibility of a more culturally appropriate and less punitive sentencing process could induce more people to plead guilty, interfering with the presumption of innocence. Indigenous people have been found to be more likely to plead guilty than non-Indigenous people, ${ }^{237}$ and, thus, any further inducement carries the risk of inappropriate pleas. The acceptance into an urban court of both those who initially accept responsibility and those who are found guilty at trial would avoid such risks. This is the practice of the New Westminster FNC ${ }^{238}$ and some judicially-led circle processes. ${ }^{239}$

The departure from mainstream procedures within the court process itself may also raise due process concerns. I discussed some of these broad issues regarding the reorientation of the judicial role in Part II. ${ }^{240}$ One answer to these concerns would be to accord judges less power to decide outcomes, allowing instead for a community-led process as discussed in Part IV.A. While community members are clearly not "objective" in the sense of the traditional judicial role, this is, in fact, a purpose of restorative justice practices — to allow those who know and understand the person appearing before the court to lead the process of healing and restitution. ${ }^{241}$

As previously noted, in many Indigenous-oriented courts, a wide variety of people, including police and probation officers, are allowed to speak to sentencing. ${ }^{242}$ For example, in British Columbia's FNCs police and probation officers speak to the nature of the healing plan that the court should mandate. ${ }^{243}$ This re-orientation of state agents from a clear adversarial position in relation to the defendant to a contributor to the person's "healing"244 could have negative impacts on that person's due process rights if these opinions are used to prejudice the defendant. The FNCs' healing plans are, despite important differences from mainstream processes and outcomes, nevertheless criminal sanctions and involve the potential for significant penalties for non-compliance. Limiting who can provide input to the court process to Indigenous community members could provide the advantages of a restorative process without the risks of state actor participation.

Aboriginal Justice, Inquiry of Manitoba, supra note 75.

Dandurand \& Vogt, supra note 34.

$R v$ Alaku (1993), 112 DLR (4th) 732 (CQ); McNamara, supra note 9.

See Nolan Jr, supra note 39; Dorf \& Fagan, supra note 72.

McNamara, supra note 9 at 32 .

See e.g. Bennett, supra note 163.

At a session of the North Vancouver FNC that I attended, the presiding judge asked a police officer present for confirmation that the defendant had been behaving appropriately in the community. The officer indicated the defendant had indeed, in the officer's perception, stayed out of trouble, however I wonder about the effect on the outcome if the officer had answered otherwise and the implications of this type of information informing judicial decisions.

244 For a description of how sentencing judges applying Gladue have sometimes repositioned imprisonment as providing healing instead of punishment, see Williams, supra note 128; Gladue, supra note 32. 


\section{Avoiding Spatial Restrictions}

In addition to creating healing plans for those who accept responsibility for an offence or who have been found guilty, an urban Indigenous court could, similar to the DCC, hold bail hearings for those charged with offences and held in detention. Such a mandate would provide the court with a much greater capacity to impact over-incarceration, given that over half of adults in prisons are in pre-trial custody. ${ }^{245}$ In addition to facilitating the release of people from prison who have not been convicted of a crime, an urban Indigenous court could ensure that unnecessary and harmful bail conditions are avoided. Canada's Criminal Code $e^{246}$ requires that those charged with offences be released unconditionally, unless the Crown can demonstrate that restrictions are required. ${ }^{247}$ However, as a number of studies have demonstrated, unconditional release is, in practice, extremely rare, with the overwhelming majority of accused receiving bail conditions that often include some form of justice system supervision and restrictions on movement. ${ }^{248}$ Courts also commonly impose spatial restrictions as part of probation conditions. ${ }^{249}$

A detailed study by researchers from three Canadian universities on the use of such spatial restrictions on marginalized people in Vancouver's Downtown Eastside (DTES) showed the destructive effect these have on people's lives by preventing access to social supports, harm reduction services, and other resources and often excluding people from the entire DTES. ${ }^{250}$ While legal actors interviewed in the study believed these conditions prevented crime and promoted rehabilitation, the people subject to them believed that they did little to address substantive crime and instead created a high likelihood of breaches and negative police contact. ${ }^{251}$ The researchers also found that most people caught breaching a spatial restriction were not charged, suggesting the conditions are mainly used as a tool to facilitate police supervision and control. Such state control over Indigenous people's movements is part of a long history of colonial efforts to displace and contain Indigenous people in order to facilitate settlement. ${ }^{252}$ By drastically reducing the use of spatial restrictions, an urban Indigenous court could reduce the role of the criminal justice system in the displacement of Indigenous communities and mitigate the destructive effect of bail and probation conditions on individuals.

\section{J. SUFFICIENT FUNDING}

As with any initiative, sufficient and stable funding is important to the success of Indigenous-oriented justice programs. Unfortunately, such support is often lacking. Many programs funded under the Aboriginal Justice Strategy have experienced significant funding

Statistics Canada, "Trends in the Use of Remand in Canada, 2004/2005 to 2014/2015" (2017), online: $<$ www.statcan.gc.ca/pub/85-002-x/2017001/article/14691-eng.pdf $>$.

Supra note 31 .

Ibid, s 515 .

Nicole Myers, "Eroding the Presumption of Innocence: Pre-Trial Detention and the Use of Conditional Release on Bail" (2017) 57:3 Brit J Crim 664 at 673-74.

Marie-Eve Sylvestre et al, "Red Zones and Other Spatial Conditions of Release Imposed on Marginalized People in Vancouver" (2017), online:<observatoireprofilages.files.wordpress.com/2017/ 10/vancouver-red-zones-report_2017-10-30.pdf $>$.

Ibid.

Ibid.

In recent years, the DTES of Vancouver has been a particular focus of colonial efforts to contain and displace Indigenous people: Blomley, supra note 180. 
uncertainty, with commitments sometimes not made until a month before the program's current funding would expire. ${ }^{253}$ For VATJSS, this has caused difficulties in staff retention and long term planning. ${ }^{254}$ While not experiencing funding uncertainty, British Columbia's FNCs receive no specific funding at all and must operate within existing provincial court operating budgets. ${ }^{255}$ By contrast, the British Columbia provincial government funded the planning and development of Vancouver's Downtown Community Court and provided a $\$ 6.225$ million capital grant to construct the courthouse. ${ }^{256}$ In addition, numerous provincial ministries and agencies provide staff resources to the Court. ${ }^{257}$ The province similarly provides the Vancouver Drug Treatment Court with $\$ 1.25$ million in annual funding ${ }^{258}$ and the federal government provides another $\$ 750,000 .{ }^{259}$ The stable resourcing of these courts allows them to provide numerous services to the people appearing before them, thereby supporting their therapeutic orientation. Similar funding would allow an Indigenous-oriented court to better support the Indigenous people appearing before it and the participation of Indigenous communities in the court process.

\section{CONCLUSION}

The settler colonial justice system of the Canadian state continues to inflict immense harm on Indigenous people. Thus, implementing the TRC's call to create Indigenous justice systems is an urgent imperative. Given that over half of those who identify as Indigenous in Canada live in urban areas, ${ }^{260}$ fully implementing the TRC's Calls to Action ${ }^{261}$ will require significant work in urban areas, one aspect of which could involve the creation of Indigenous courts. While the development of such courts within the confines of the Canadian justice system carries significant limitations, the practices of existing courts show ways in which Indigenous people and communities can exercise substantial input and control over court processes and Indigenous legal principles can be enacted. At the least, this could play a critical role in reducing the harm caused by the settler justice system and, perhaps, could be a step towards a decolonized approach to justice.

Palys, "VATJSS," supra note 103 at 34.

Ibid.

Johnson, supra note 9 at 10.

Ministry of Justice, "Report from the DCC Executive Board," supra note 210 at 3-4.

British Columbia Ministry of Justice, "Downtown Community Court in Vancouver Efficiency Evaluation" at 6, online: <www2.gov.bc.ca/assets/gov/law-crime-and-justice/courthouse-services/com munity-court/dcc-efficiency-evaluation.pdf $>$.

Johnson, supra note 9 at 10 .

Department of Justice, "Drug Treatment Court," supra note 39 at 6.

Statistics Canada, “Aboriginal Peoples in Canada: Key Results From the 2016 Census" (2017), online:

$<$ www.statcan.gc.ca/daily-quotidien/171025/dq171025a-eng.pdf $>$.

Supra note 1. 
[this page is intentionally blank] 